\title{
Energy Reclassification and Its Significance To Highlight Unconventional Energy In the Oil and Gas Industry
}

\author{
Yaming Yao ${ }^{1}$, Jianjun Chen ${ }^{2}$ \\ ${ }^{1}$ College of Geosciences and Engineering North China University of Water Resources and Electric \\ Power, Zhengzhou 450046 China \\ ${ }^{2}$ School of Earth Sciences and Engineering, XI'AN Shiyou University, Xi'an 710065 China
}

\begin{abstract}
In recent years, the rapid rise of non conventional energy, the formation of the new energy and conventional energy, a situation of tripartite confrontation pattern.In order to enable the people to the energy characteristics, uses, the relationship between them have a more clear understanding, therefore, It is necessary to energy re definition and classification. In this paper, through the current energy structure, distribution, usage. From the angle of Genesis will be divided into three types, Namely:from the earth itself, since the other planet in the universe and from two interactions. At the same time, the non conventional energy is the future of a new type of energy. However, it belongs to the oil and gas industry.Analysis of global and China's major non conventional energy resources potential, exploration type, present situation of exploitation. And the geological theory and engineering problems, It points out its characteristics, and points out the close relation between it and conventional energy. In particular, points out the necessity and significance of the development of China's non conventional energy.
\end{abstract}

Keywords: Energy, genetic classification, non-conventional energy, oil and gas Industry, the relation and the difference between, Resource potential, characteristics of exploitation .

\section{Generation}

Energy is the lifeline of national economy, which is essential for people's production and various daily activities, especially in nowadays society, the significance of energy is more important and energy has become one of the four resource elements, which is parallel with air, water and food. Looking back to the history, each progress of human society has an inseparable relationship with energy revolution. Fuelwood energy brought agriculture civilization; coal energy initiated the industrial revolution era; petroleum energy promoted modern social civilization; natural gas energy leads to modern green civilization. Of course, clean energies such as electricity of coal, oil, air also bring us more profound changes. We can say that the earth where we are living in is more and more inseparable from the energy, of course the earth is providing various energies for us.

ISSN: 0010-8189 
Unconventional energies rose rapidly, especially in recent years. With successful surface mining of coal bed methane, it overturns the previous discharge conducted under the well for coal mine safety and does not hold the traditional concept of considering it as an available resource to discharge into air. Successful mining of shale gas accelerates the understanding of unconventional energies for people and American's successful mining of shale gas is called the shale gas revolution. According to the scientists researches, the natural gas hydrate reserved in the bottom of ocean and permafrost on the land is the biggest part of unconventional energies, which can meet the needs of human for thousands of years[1].

When it comes to this issue, you may ask now that coal, oil, natural gas, water and electricity, nuclear power, or solar energy, wind power generation, or bio-oil, all of these are energies, so how to divide them? What's the relationship between them? What are the usages respectively? How about the prospect of unconditional energies?

\section{Energy and Current Situation}

\subsection{Definition of energy}

Energy is the substance which provides energy transformation for nature and is the material basis of human activities. Specifically speaking, energy is the general term of substances which can generate all kinds of energies (such as heat, electric energy, optical energy and mechanical energy) or materials which can make power. To some sense, the development of human society is inseparable from the occurrence of high-quality energies and advanced energy technologies. In modern society, energy development, energy and environment is the common issue concerned by the human and the world and also an important issue of social and economic development for our country.

People talked little about the term of "energy" and it became the hot spot due to the twice oil crisis. Energy is the basic driving force of the development of the whole world and economic growth and the foundation of human survival. Energy security issues began to appear since the industrial revolution. With the rapid development in the globalization of the international economics, international energy security rises to the height of the country and each country has established the energy policy with core of energy supply security. In the later twenty years, the world economy achieves great growth with the support of stable energy supply. However, people also meet a series of inevitable energy security challenges when they share the benefits of economic development and scientific and technological progress brought by energies. Energy shortage, resource competition and environmental pollution caused by excessive use of energy and other issues threaten the survival and development of human.

\subsection{Situations at home and abroad}

Nowadays, each country has recognized that oil and gas resources become less for mining and it can be obviously observed from the oil price in recent ten years which was increased to about 100 dollars from 20 dollars(At present, the price of crude oil has fallen back to about \$60). Meanwhile, all countries are looking for new alternative energies. For example, France, Japan and other countries vigorously develop unclear power, Germany and other EU countries vigorously develop solar energy and America and Canada focus on unconventional energies. However, China ISSN: 0010-8189 
develops towards to multi-energy direction according to the actual situations.

Both the table above and the actual situation in our country reflect the energy problems in our country. Our country is facing up with two relatively serious energy problems. The first one is the huge gap of supply and demand of oil and gas; a large amount of petroleum and natural gas are imported from overseas every year. In 2020, crude oil of 542 million tons and 135 billion cubic meters of natural gas were imported with respective degree of import dependence $74 \%$ and $43 \%$, especially the petroleum whose degree of import dependence has greatly exceeded psychological defense line of $50 \%$ and will have a strong impact on national energy strategy security. The second problem is the unreasonable energy structure; coal accounts for as high as $56.7 \%$ in our country's energy structure, which will not only pollutes atmospheric environment but also does harm to people's health.

At present, although various countries in the world have taken many measures, such as energy conservation and development of new types of renewable energy sources, they have not changed the situation fundamentally. For solar energy, wind energy, nuclear energy and other renewable resources starting to be used, oil and gas resources can hardly be replaced in short period; for bio-oils under development, there is a risk of its competing for food with humans; for coal chemical industry under implementation, the environmental pollution it causes could not be ignored.

\section{Genetic Classifications of Energy}

In terms of formation itself, there are three main kinds: the first kind comes from earth itself, for example, natural gas of inorganic origin from the deep earth, terrestrial heat produced by earth itself, uranium ores formed under mineralization of earth which is raw material of nuclear energy power generation and topographic relief of earth surface creates conditions for hydro power; the second comes from other planets in universe, like solar energy, tidal energy and so on; and the last one is the result of interaction between earth and other planets, like fossil energy, including coal, petroleum, natural gas, which is formed by physical and/or chemical action of remains of organisms buried, and bio-energy, including marsh gas, bio-oil, etc. which is directly transformed from biology because biological growth could not be possible without the sun. At present, energy is usually divided into three main categories, namely conventional energy, unconventional energy and new energy. The specific classification is as follows:

3.1 Energy can be divided as follows according to its form:

(1) Solid: coal, asphalt, oil shale, uranium ore;

(2) Liquid: petroleum, shale oil, terrestrial heat, hydraulic power;

(3) Gas: natural gas, coal bed methane, shale gas, natural gas hydrate, mantle gas, methane.

ISSN: 0010-8189

(C) CONVERTER 2020

www.converter-magazine.info 
3.2 Energy can be divided as follows according to formation effect:

(1) Physical: solar energy, wind power, hydro power, nuclear power, coal power;

(2) Chemical: hydrogen power;

(3) Biology: methane, shallow biogas;

(4) Comprehensive: coal, petroleum, natural gas and other conventional energy, and coalbed methane, shale gas, natural gas hydrate and other unconventional energy.

3.3 Energy can be divided as follows according to its mining way and application order:

(1) Conventional energy: coal, petroleum, natural gas, hydraulic power;

(2) Unconventional energy: coal bed methane, shale gas, oil shale, natural gas hydrate, tight gas, asphalt, oil sand;

(3) New energy: solar energy, wind energy, tidal energy, bio-oil, nuclear energy, geothermal energy.

3.4 Energy can be divided as follows according to source:

Direct source: primary source; Indirect source: secondary source.

Primary energy or natural energy refers to energy exist in nature, like coal, petroleum, natural gas, hydro-energy, etc.

Secondary energy refers to energy product processed and transformed from primary energy, such as electric power, coal gas, vapor and various petroleum products and so on.

3.5 Energy can be divided as follows according to its location in earth:

ISSN: 0010-8189

(C) CONVERTER 2020

www.converter-magazine.info 
(1) Earth surface: wind energy, solar energy, tidal energy, hydro power, bio-oil, methane, etc.

(2) Earth interior: petroleum, natural gas, coal, uranium ore, thermal energy, oil sand, oil shale, flammable ice, etc.

3.6 Energy can be divided as follows according to property:

(1) Fuel-type energy (coal, petroleum, natural gas, peat, wood);

(2) Non-fuel type energy (hydro energy, wind energy, geothermal energy and ocean energy).

3.7 Energy can be divided as follows according to whether it will cause environmental pollution after consumption:

(1) Dirty energy and clean energy; dirty energy includes coal, petroleum and so on.

(2) Clean energy includes water power, electric power, solar energy, nuclear energy and so on.

3.8 Energy can be divided as follows according to whether it is repeatedly obtainable:

Renewable energy and non-renewable energy. Primary energy is further classified by people: energy that can be continuously supplemented or regenerated in relatively short period is called renewable energy; otherwise is non-renewable energy.

Wind energy, hydro energy, ocean energy, tidal energy, solar energy, biomass energy, etc are renewable energy.

Coal, petroleum, natural gas and so on are non-renewable energy.

\section{Unconventional Energy Resources}

With the innovation of theory and technology, breakthrough has been made towards limitation existing in conventional reservoir physical property and idea of oil detection in conventional entrapment. According to statistics of U.S. federal geological survey and U.S. department of energy, quantity of global unconventional petroleum ISSN: 0010-8189 
resources reaches $4495 \times 10^{8} \mathrm{t}$, which is about the same as that of conventional petroleum resources; quantity of global unconventional natural gas resources reaches $3922 \times 10^{12} \mathrm{~m}^{3}$, which is eight times of that of conventional natural gas resources. Unconventional oil and gas resources play an increasingly important role in global energy structure and are a strategic field of future oil and gas exploration. Immediate further study of unconventional oil-gas geology needs to be carried out.

Comparative to conventional energy, namely coal, oil and gas, energies like coal bed methane, shale gas, oil sand, oil shale, tight oil and gas, etc. are called as unconventional energy. Obviously, these energies have much in common, namely, they are all fossil energy and formed in oil-and-gas-bearing basins (or coal-bearing basins), whose formation and distribution are closely related to the formation and accumulation of unconventional energy. So to speak, most of the unconventional energies belong to the same oil and gas energy of different periods and stages. Compared with conventional energy, advantages of unconventional energy are of more types, wider distribution and larger amount of resources[14].

\subsection{Resource types and potentials}

\subsubsection{Unconventional oil and gas resources in the world are abundant with great potential}

According to the latest statistics of Energy Information Administration of U.S. Department of Energy, shale oil in the world may reach $4110 \times 10^{8} \mathrm{t}$, which is over $50 \%$ more than conventional petroleum resource $\left(2710 \times 10^{8} \mathrm{t}\right)$. It is mainly distributed in countries like America, China, Russia, Canada, Zaire, Brazil, Estonia, and Australia and so on. According to statistics of U.S. Geological Survey (USGS), quantity of recoverable resources of oil sand in the world is about $6510 \times 10^{8} \mathrm{bbl}\left(1 \mathrm{bbl}\right.$ equals to $0.158987 \mathrm{~m}^{3}$ ), accounting for $32 \%$ of total amount of recoverable resources of oil sand in the world $\left(20370 \times 10^{8} \mathrm{bbl}\right)$, which has become an important part of world energy structure. The distribution of oil sand resources is extremely unbalanced which is mainly in countries and regions of North America, Russia, Latin America, the Caribbean, etc.

The quantity of global coal bed methane resources reaches $256.3 \times 10^{12} \mathrm{~m}^{3}$, which is about $50 \%$ of conventional natural gas resources; thereinto, quantity of coal bed methane resources of five countries, Russia, Canada, China, America and Australia, accounts for $90 \%$ of that of in globe. Quantity of global shale gas resources reaches $456.2 \times 10^{12} \mathrm{~m}^{3}$, mainly distributed in countries and regions of North America, central Asia, and China, Latin America, the Middle East and North Africa, former Soviet Union, etc. Unconventional oil and gas resources are extremely rich for the global perspective, which are the best supplement to conventional energy of oil and gas.

According to research results of America, Russia, Japan, etc. total amount of global natural gas hydrate in land is $2.83 \times 10^{15} \mathrm{~m}^{3}$, in oceans $8.5 \times 10^{16} \mathrm{~m}^{3}$, which is as more than twice as total carbon content of proven fossil fuels. Natural gas hydrate is in huge resources with reserve-production period of at least one hundred years[5].

4.1.2 China is rich in unconventional oil and gas resources with various types and wide distribution

ISSN: 0010-8189 
Evaluation results of national oil shale resources in 2006 show that quantity of geological resources of shale oil in our country is $476.44 \times 10^{8} \mathrm{t}$, ranking second in the world, which is mainly distributed in eastern area, Qinghai-Tibet and central area. Proven reserves of shale oil is $20 \times 10^{8} \mathrm{t}$, which is mainly distributed in provinces of Jilin, Guangdong, Liaoning, etc. Quantity of oil sand resources in our country is $59.7 \times 10^{8} \mathrm{t}$, which is mainly distributed in western and eastern basins in land, with key distribution in basins like Junggar, Qaidam, Songliao, Ordos, Tarim, Szechwan, etc. Quantity of geological resources of oil sand in the 11 main basins account for $97.6 \%$ of the national ones in total, and $97.54 \%$ of the total recoverable resources.

Total amount of national coal bed methane resources is $36.8 \times 10^{12} \mathrm{~m}^{3}$, ranking third in the world; thereinto, quantity of recoverable resources of shallow coal bed methane with 1000 meters deep is $6.27 \times 10^{12} \mathrm{~m}^{3}$. Total amount of coal bed methane resources of eight basins whose resources is more than $1 \times 10^{12} \mathrm{~m}^{3}$, is $28 \times 10^{12} \mathrm{~m}^{3}$, accounting for $76 \%$ of the total resources. And shale gas resources in our country also have great potential. According to statistics, prospective resources of shale oil may reach $100 \times 10^{12} \mathrm{~m}^{3}$, which is as twice as conventional natural gas resources. It is mainly distributed in Sichuan Basin and Tarim Basin in Sinkiang. Quantity of tight sandstone gas resources in our country is about $12 \times 10^{12} \mathrm{~m}^{3}$, part of which is overlapped with conventional gas.

Proceeding from our national conditions, short supply of oil and gas resources can be made up by the active development of exploration and exploitation of unconventional oil and gas resources.

4.2 Research progress of unconventional oil and gas

\subsubsection{Overseas research progress}

Research in unconventional oil and gas geology can be dated back to 1930s, when W.B.Wilson (1934) proposed open oil and gas reservoir in classification of oil and gas reservoir; although it was considered to be worthless for exploration, it showed that Wilson already predicted the existence of unconventional oil and gas reservoir. The unconventional oil and gas resources haven't drawn much attention because of low grade, poor reservoir stratum, complex accumulation mechanism, difficult exploration and exploitation; petroleum geologists didn't shift their attention into research on location of unconventional oil and gas resources until 1990s when unconventional oil and gas resources, like basin-centered gas (B.E.Law, 2002), coal bed methane (W.B.Ayers Jr, 2002), shale gas (Nielson, 1990), tight sandstone gas (J.A.Masters, 1979) and shale oil (H.W.Parker, 1970), etc. gradually became one of the subject of reserve increase with the direction shift of oil and gas exploration and progress of technology. With efforts of nearly 20 years, achievements have been made in unconventional oil-gas geology, which covers various aspects of unconventional oil and gas resource, like its content, types, geologic features, ways of evaluation and technology of exploitation, etc.

Schmoker and Gautier et al from USGS proposed concept of "continuous-type oil and gas reservoirs", which referred to trapped oil and gas resources that were in clumped distribution in large area of unconventional reservoir stratum like tight sandstone, coal bed, shale, etc. in petroliferous basins and which were lack of clear cover coat boundaries and short of clear oil-gas-water interface in general. USGS evaluated natural gas resources like tight sandstone gas, shale gas, basin-centered gas, coal bed methane, shallow biogas and natural gas hydrate based on the concept. B.E.Law et al (2002) proposed the concept of unconventional oil and gas system, thinking that it had nothing to do with structural trap and was not subject to gravitational differentiation basically, and there was general petroliferous

ISSN: 0010-8189

www.converter-magazine.info 
zone in large scale in region. And they made a brief introduction to several unconventional natural gas resources like coal bed methane, deep basin gas and natural gas hydrate.

"Petroleum Resources Management System" jointly issued by APE, AAPG, WPC and SPEE in 2007, defines relevant concepts of unconventional oil and gas resources, thinking that continuous-type deposit and unconventional resources are basically the same, which refer to oil-gas accumulation with continuous distribution in large scale and small hydrodynamic force, including basin-centered gas, shale gas, natural gas hydrate, natural asphalt and oil shale, etc. And the essay puts emphasis on its technological difficulties and economic feasibility at the same time[6-7].

\subsubsection{Domestic research progress}

With the transformation of domestic oil and gas resource structure, unconventional oil and gas resources like deep basin gas, tight sandstone gas, shale gas, coal bed methane, shale oil and so on, gradually become the new field of oil and gas exploration, thus drawing attention of domestic scholars to geological research of unconventional oil. Chinese scholars brought in and put forward concepts of seep basin gas, tight sandstone gas, deep basin oil and syncline oil, etc. Combining related research results of U.S. federal geological survey with Chinese oil and gas exploration practice, Chu Caineng (2009) put forward the concept of "continuous-type" oil and gas reservoir, which referred to unconventional trapped oil and gas reservoir with oil and gas continuously distributed in unconventional reservoir system of large scale, and he systematically explicated its geologic features, resource potential, evaluation and exploitation methods. On this basis, Chu Caineng (2010) put further emphasis on importance of research on unconventional oil and gas geology, emphasizing research, evaluation and exploitation of unconventional resources, unconventional reservoir stratum, unconventional accumulation, exploitation technology of unconventional oil and gas, especially the formation mechanism of micro reservoir space in micron and nanometer size, oil and gas migration and accumulation and its distribution regularities, economic recoverable reserves and development strategy, etc.

\subsubsection{Author's research progress}

For conventional oil and gas, six major elements of oil and gas accumulation, namely generation, storage, cover, entrapment, migration and preservation of oil and gas, happen in big system of basins; while shale gas occurs in small system of generation in the six major elements, in other words, generation, migration and storage, etc. All happen in source rock, i.e. Shale; to be more exact, they happen within the series of shale strata.

\subsubsection{Unconventional oil and gas is the succession and development of conventional oil and gas}

For conventional oil and gas, six major elements are generation, storage, cover, entrapment, migration, preservation, plus adjustment and damage. There was nothing wrong with behavior of only caring for oil and gas reservoir of conventional oil and gas (formed at once, after adjustment) at that time and this was the only way because of limitations of theory, method, technology and other conditions.

Unconventional oil and gas includes coal bed methane, shale gas, shale oil, tight gas, tight gas, deep basin gas, natural gas hydrate, oil sand, oil shale, heavy petroleum asphalt and so on.

ISSN: 0010-8189 
It is fine that unconventional oil and gas is extremely hot right now, but this could not be the reason of rejecting and ignoring conventional oil and gas. It is called unconventional oil and gas to be relative to conventional oil and gas. Correct understandings and attitudes rather than opposition are succession and development of conventional oil and gas[8-9].

4.2.3.2 Unconventional oil and gas is the epitaxy of conventional oil and gas, and is extension and expansion of content

If conventional oil and gas were placed on outstanding and turning point (actually it should be so), then forward extension would be tight oil, tight gas, seep basin gas, natural gas hydrate, and further forward would be shale gas, coal bed methane, shale oil; and backward extension would be oil sand, asphalt, heavy oil, oil shale and so on whose oil reservoir are destroyed (or products of deepened evolution).

What changes is the time-space relationship rather than substances generating oil and gas; from the perspective of time, it starts earlier and ends later; from the perspective of space, scope of space becomes lager no matter it is longitudinal space or transverse space.

4.2.3.3 Connecting and separating role of oil migration plays between conventional and conventional oil and gas

According to theories of conventional oil and gas, including Tissot oil-generation theory, oil and gas migration are divided into primary migration and second migration which is too familiar to everyone to mention.

I want to call migration that happens within source rock as pre-primary migration during which stage coalbed methane, shale gas and shale oil are formed.

Call the migration that happens soon after oil and gas comes out from source rock as post-primary migration or pre-second migration during which stage tight oil, tight gas, deep basin gas, natural gas hydrate and so on are formed.

And then call migration that happens after oil and gas reservoir is destroyed as post-second migration during which stage oil shale, oil sand, asphalt, etc. are formed[10].

\subsubsection{Concept of big system and status improvement of oil-generating (or gas-generating) quantity}

When it comes to conventional oil and gas, there is a petroleum system that is familiar to everyone. Here, I define conventional oil and gas and conventional oil and gas as a system; just as what is mentioned before, connect them with oil and gas migration and the system is called as energy system for the moment. It is obvious that the energy system is larger than petroleum system. In the energy system, classifications are not made according to generation, storage, cover, entrapment, migration and preservation, etc. But according to shale gas, shale oil, tight gas, tight oil, conventional gas and oil, oil sand, asphalt and so on. Thus several aspects must be taken into consideration.

First of all, source rock status is much higher, and more of the oil and gas it generates can be exploited.

ISSN: 0010-8189

(C) CONVERTER 2020

www.converter-magazine.info 
Second, since oil-generating quantity of a basin (depression, downwarp) is certain, amount of unconventional oil and gas in places with much conventional oil and gas may be relatively less and vice versa.

Third, reevaluate all of the petroliferous basins, even those basins that were considered to be lack of reservoir, entrapment, cover coat and preservation conditions. The role quantity of resources (basin resources calculated at conventional oil and gas) plays must be less important, and accordingly role oil migration plays will be more importan[11-13]t.

\section{Chances of Developing Unconventional Energy in Our Country}

\subsection{Energy situation}

Since entering new energy, China's energy demand is growing sharply and quickly. Total energy production is 135,048 million tons standard coal in 2000, 171,906 million tons standard coal in 2003 and it increased to 247,279 tons standard coal in 2007 and it even increased to 317,987 tons standard coal in 2011. China's total primary energy production reach 3.97 billion tons of standard coal In 2019.Accordingly, energy import volume increased year by year, too.

At the same time, China is a country rich in coal while short of oil and gas. Structural proportion in energy structure of 2019 was: $57.7 \%$ of raw coal, $18.9 \%$ of crude oil, $8.1 \%$ of natural gas, $15.3 \%$ of hydro power, nuclear power and wind power. Although new energy and renewable energy have been greatly developed, the status of traditional energy could hardly be shaken. The great harm that $57.7 \%$ of use of raw coal does to the environment and people's health could not be underestimated.

\subsection{Unconventional resources}

Unconventional natural gas accounts for $84.6 \%$ of natural gas resources in China. Quantity of unconventional natural gas resources is 306.6 trillion cubic meters (among which hydrate accounts for 13.18 billion cubic meters), and quantity of conventional natural gas resources is 56 trillion cubic meters which is one fifth of conventional natural gas resources. In conventional natural gas resources, coal bed methane accounts for 36.8 trillion cubic meters, shale gas 126 trillions, tight sandstone gas 12 trillion and hydrate 131.8 trillions[14-16].

\subsubsection{Shale gas}

There are mainly marine facies, marine-continental transitional facies, continental facies, these three sets of shale, namely Paleozoic marine facies shale, Meso-Cenozoic continental facies shale and Permo-Carboniferous transitional facies shale. To be more concrete, marine facies is distributed in three major regions: Paleozoic erathem in southern

ISSN: 0010-8189 
region, Paleozoic erathem in North China and Cambro-Ordovician in Tarim basin; continental facies is distributed in six major basins: Cretaceous of Songliao Basin, Palaeogene of Bohai Bay Basin, Triassic-Carboniferous of Ordos Basin, Carboniferous-Jurassic system of Junggar Basin, Jurassic of Tuha Basin, Palaeogene/ Mesozoic Erathem of China offshore basins; shale oil and shale gas can be formed in all these regions[11].

\subsubsection{Coal bed methane}

Coal bed methane resources in China are mainly distributed in four major regions. According to latest evaluation results, quantity of geological resources of shallow coal bed methane in 42 major gas-bearing basins with burial depth of 2000 meters is 36.81 trillion cubic meters and quantity of recoverable resources is 11 trillion cubic meters. Low-middle ranking coal bed methane (accounting for 77\%) is the main type of coal bed methane resources in China, among which low-ranking coal accounts for 43\%, middle ranking coal $34 \%$. Exploration and exploitation of coal bed methane in China are extremely low with huge potential of remaining coal bed methane resources undeveloped[10].

\subsubsection{Natural gas hydrate}

Important progress of exploration of natural gas hydrate in China has been achieved in recent years, and natural gas hydrate samples have been obtained in deep waters and land of China.

In May 2007, natural gas hydrate has been exploited in the Shenhu deepwater area of northern of South China Sea. According to preliminary forecasting, quantity of perspective resources of natural gas hydrate in deepwater area of northern of South China Sea is 18.5 billion tons of oil equivalents; and that of southern of South China Sea and deepwater area of the East China Sea is 78 billion tons of oil equivalents.

In September 2009, natural gas hydrate samples have been successfully exploited in Muli coal field of permafrost region in the southern margin of Qilian Mountain in Qinghai City. According to early estimates, quantity of prospective resources of natural gas hydrate in permafrost region of China is at least 35 billion tons of oil equivalents.

\subsubsection{Tight sandstone gas}

Tight gas of China is of wide distribution and tremendous resource potential. More than 10 basins including basin of Sichuan, Erdos, Songliao, Bohai Bay, Tarim, Qaidam and Jugger have favorable geological conditions for the formation of tight sandstone gas reservoir. A early as 1997, Rogner had evaluated tight gas resources, and quantity was about $11 \sim 14 \times 10^{12} \mathrm{~m}^{3}(400 \sim 500$ trillion cubic feet).

According to the second round of evaluation results of natural gas resources in China, onshore natural gas resources in China is $30.23 \times 10^{12} \mathrm{~m}^{3}$.

\subsection{Strive to develop clean energy}

ISSN: 0010-8189

(C) CONVERTER 2020

www.converter-magazine.info 
On the one hand, using natural gas in a great amount brings people's lives great convenience. Natural gas consumption regions have expanded to all cities, districts and provinces in mainland of China and nearly 0.5 billion people have enjoyed the convenience brought by clean energy with high efficiency in 2019. "The 14th Five-Year Plan" is a key period to comprehensively construct modern resources industry system and also an important period for natural gas industry to reach a higher level. During "the 14th Five-Year Plan", the supply layout of "the west-east natural gas transportation, the north-south natural gas transmission, the maritime gas going ashore and external supply in the neighborhood" will be shaped in China. Natural gas consumption in China is expected to be approximately 340 billion cubic meters in 2021. Penetration rate of gas consumption will be further enhanced. Supply capacity will exceed 360 billion cubic meters (including unconventional natural gases and imported natural gases such as coal bed methane, shale gas and coal-based natural gas).

On the other hand, although output of natural gas in China increases year by year, the consumption increase rapider. Nationwide output of natural gas reached 161.02billion cubic meters in 2017with an increase of $7.5 \%$ over the previous year. However, the imported LNG reached 73.6billion cubic meters with an increase of $43.2 \%$ and imported pipeline gas reached 51.4 billion cubic meters. over the same period.

The output exceeded 170 billion cubic meters for the first time and reached 173.62 billion cubic meters in 2019; however, the consumption reached 300billion cubic meters (natural gas import exceeds 130 billion cubic meters) over the same period. Accumulated output of natural gas reached 188.8 billion cubic meters in 2020 with an increase of $9.8 \%$ over the same period of previous year; however, the consumption reached 320 billion cubic meters (natural gas import exceeds 140 billion cubic meters) over the same period with an increase of $6.8 \%$ over the previous year. In addition, the proportion of natural gas in primary energy exceeded 9\%; natural gas import further increased (imported pipeline gas would reach 50 billion cubic meters and LNG would be equivalent to900billion cubic meters in approximate 140 billion cubic meters of import in 2020) with an increase of $8 \%$ over 2019; foreign-trade dependence exceeded $43 \%$.

As it can be seen from the above, natural gas consumption in China is 340 billion cubic meters in 2021; conventional natural gas output may reach 170 billion cubic meters at most in 2021 in accordance with the calculation based on current conventional natural gas and less than $10 \%$ of growth rate; thus, the insufficiency will be 170 billion cubic meters, which needs to be implemented by unconventional natural gases and imported natural gases such as coal bed methane, shale gas and coal-based natural gas. However, imported natural gases have already been in large amount and restricted by numerous factors with a security risk line like petroleum; coal-based natural gas, of which the production process consumes lots of water resources and generates carbon dioxide and waste water in large amount, does not conform to direction of low carbon economy with high costs, which may be regarded as technical reserve[15-18].

\section{Present Status of Unconventional Exploitation}

6.1 Unconventional oil and gas resources have been paid more and more attention; and commercial exploitation has been carried out

ISSN: 0010-8189

(C) CONVERTER 2020

www.converter-magazine.info 
Oil shale is of various types with a long history of exploitation. Currently, $69 \%$ of oil shale of the world is used for generating electricity and supplying heat; $25 \%$ for extracting shale oil; $6 \%$ for architecture, agriculture and other aspects. Oil shale output of the world $156 \times 10^{4} \mathrm{t}$ in 2012 , which is mainly distributed in China, Estonia, Brazil, Australia and other countries. Oil shale of China is mainly yielded by Liaoning Fushun Mining Group, of which the annual yield in 2005 was $20 \times 10^{4} \mathrm{t}$ and annual yield in 2007 was approximately $30 \times 10^{4} \mathrm{t}$.

Canada is the only country which achieves commercial exploitation of oil sand in the world with $4810 \times 10^{4} \mathrm{t}$ of yield of oil sand bitumen in 2002 accounting for $48 \%$ of petroleum supply volume of Alberta Province and $6170 \times 10^{4} \mathrm{t}$ of yield in 2005 and an increase to $7280 \times 10^{4}$ t of yield in 2006 .

Currently, America, Canada and Australia have commenced commercial production of coalbed methane, of which the yield respectively reached $540 \times 10^{8} \mathrm{~m}^{3}, 18 \times 10^{8} \mathrm{~m}^{3}$ and $60 \times 10^{8} \mathrm{~m}^{3}$ in 2006 . Yield of coalbed methane in China was $3.8 \times 10^{8} \mathrm{~m}^{3}$ in $2007,72 \times 10^{8} \mathrm{~m}^{3}$ in 2009 and $126 \times 10^{8} \mathrm{~m}^{3}$ in 2012 .

America is the most successful country in exploration and exploitation of shale gas in the world, which has been rapidly developing since 2006 due to promotion of horizontal well technology and fracturing technology. Currently, works input of exploration and exploitation of shale gas in America has greatly increased. The number of shale gas wells reached 98590 in 2009, more than twice as many as that in 2006; yield of shale gas rapidly rose and reached $1378 \times 10^{8} \mathrm{~m}^{3}$ in 2010 , seven times as many as that in 2005 . There is a huge potential in follow-up resources, of which the reserve was verified to reach $17162.2 \times 108 \mathrm{~m}^{3}$ in 2009 with an increase of $76 \%$ over the previous year. Shale gas, of which the yield reached $2653 \times 10^{8} \mathrm{~m} 3$ and accounted for $37 \%$ of all natural gases in 2012 , becomes a kind of important natural gas resources. Shale gas reached $6122 \times 10^{8} \mathrm{~m}^{3}$, in 2018 .

There are more than 40000 yielding wells of tight sandstone gas among 900 gas fields in America, of which the annual gas yield reaches $1800 \times 10^{8} \mathrm{~m}^{3}$,in $2012[17-20]$.

6.2 Form the characteristics of unconventional energy research and exploitation in China

Currently, tight sandstone gas has gone into scale exploitation phase; the exploitation and utilization of coalbed methane and shale gas is commencing; basic research of natural gas hydrate and other resources is gradually carried out.

\subsubsection{Geology characteristics of unconventional natural gas in China:}

Widely distributed in north, south and middle; Combination of deep, middle and shallow bed series; Both continental sedimentation and marine sedimentation; Complex physical property of reservoir stratum; Intergrowth and co-existence of general and conventional oil and gas.

ISSN: 0010-8189 
6.2.2 Exploitation theory and awareness for unconventional natural gas in China

Through many years of persistent exploration, a series of theory and awareness for unconventional natural gas in China has formed in exploration, geology, exploitation and other aspects.

6.2.2.1 Theory and awareness for tight gas (tight sandstone, volcanic rock and carbonate rock)

Theories and awareness, such as superelevated, constructive and large river delta, low-speed deformation flow, three renewals, dual breakthrough, intrusive phase of volcanic rock in ultra-shallow bed, multi-phase separation and accumulation of carbonate rock bed series in marine facies, have formed. China's tight sandstone gas production will exceed 60 billion cubic meters,In 2019.

\subsubsection{Exploitation principles and theoretical awareness of coal bed methane}

Theories and experience, such as "double hump" curve, theory of physical adsorption, awareness of, area pressure reduction and stable discharge and exploitation, isothermal adsorption model, fractal adsorption model of coalbed methane of low coal rank and "method of five sections and two points" management, have formed.In 2019, Coal bed methane production will reach 8.88 billion cubic meters, with a year-on-year growth of $13.8 \%$.

\subsubsection{Formation principles and theoretical awareness of shale gas}

Principles and awareness, such as formation concept of mudstone fracture porosity and permeability, fractured accumulation of mud shale, occurrence theory of dissociation method, marine facies superior to continental facies and biogenesis and thermogenic, have formed. In 2020, shale gas production will exceed 20 billion cubic meters. Although it started late, it has made rapid progress.

\subsubsection{Exploitation technology system of unconventional natural gas in China}

Through many years of persistent efforts, a series of key technologies have formed for primary exploration of unconventional natural gas in China, of which some technologies have reached advanced level in the world: (1) 2-dimension seismic technology with high precision (integrated innovation); (2) Selection technology of enrichment region and well position (integrated innovation);(3) Drilling and completion techniques for coalbed methane (advanced in China); (4)Feathery and multi-branch well drilling technology (new technology with low costs; advanced in the world); (5)Drainage and gas extraction technology for coalbed methane (Qinshui Basin; mature technology); (6)Horizontal well drilling technology (mature technology); (7)Horizontal well staged fracturing and transforming technology (breakthrough test is being carried out in Daqing, Changqing and Jilin Oilfield); (8) Drainage and gas extraction technology for tight gas and etc[19-22].

\subsection{Main existing problems}

ISSN: 0010-8189 
Can these resources in a large quantity give rise to yield immediately? It is not exactly so. First of all, it is called unconventional energy relative to conventional energy. Compared with conventional energy, the advantages of unconventional energy are various types, wide distribution and large resources; however, its disadvantages are also obvious-low abundance, poor physical property and high costs. Secondly, for the reasons why America can obtain rapid success of exploitation and utilization, the first one is benefits from advanced and effective technologies, such as well drilling on long-distance and horizontal section, large hydraulic staged fracturing; the second one is benefits from vigorous support policies, for example, national legislation and revenue give great support to development of unconventional natural gas. Especially the latter one plays a more important role in exploitation and utilization unconventional energy.

In fact, three conditions are needed for the development of unconventional energy at the same time: the first one is good resource basis; the second is advanced and applicable exploitation technology; the third one is vigorous support policies from the governmen[13]t.

\subsubsection{Geological conditions of unconventional oil and gas with complexity and particularity}

Unconventional oil and gas reservoir, of which accumulation conditions are complex and different types of resources are of different characteristics, is with tight reservoir stratum and strong anisotropy. Oil shale and tight sandstone belong to reservoir stratum with low permeability and have an extremely low permeability. Coalbed methane reservoir stratum possesses the characteristics such as strong anisotropy of contained gas, low permeability, low pressure on reservoir stratum and low saturation degree of contained gas. Shale gas of marine facies is deeply buried (Tarim) and highly evolved (Sichuan) with a low content of brittle mineral and strong late reformation (Sichuan).

\subsubsection{Some development technologies with immaturity and poor applicability}

Currently, development of unconventional oil and gas mainly takes example by experience of conventional oil and gas; unique technology has not formed yet. Fracture formation theory during construction process of fracturing stimulation is still unaware. Further study is needed. In addition, there exists difficulties, for example, failure rate of branch well drilling is high; on-site test of in-situ exploitation technology for oil shale has not been carried out; it is quite difficult for geophysical exploration technology to identify oil stand bed.

\section{Conclusion and Awareness}

It can be seen from classifications above that on the one hand, resources of the world is of various types and widely distributed; one the other hand, the energy truly environment-friendly and economic with high efficiency is scarce; in addition, energy distribution in various countries is quite unbalanced. It is believed that classification of energies will be more scientific and reasonable with continuous improvement of science and technology and continuous appearance of new energies.

Unconventional oil and gas resources are rich in China; Coal bed methane, oil sand, oil shale, tight sandstone gas and shale gas are the most realistic unconventional oil and gas resources currently.

ISSN: 0010-8189 
Conventional energy, especially the relation conventional energy with shall not be forgotten when works with respect to the unconventional energy is carried out.

A great deal of researches are needed to be carried out to substitute unconventional energy for conventional energy in China due to the impacts of the following factors: geological conditions of unconventional oil and gas with complexity and particularity; some development technologies with immaturity and poor applicability; a low yield of single well in reservoir stratum with low permeability and a lack of effective yield increase technology; low comprehensive utilization efficiency, severe environmental pollution, etc.

\section{Acknowledgements}

Projects supported by Natural Science Foundation of Xinjiang Uygur Autonomous Region (project number: 2019D01A34) "Reservoir forming mechanism, occurrence characteristic and basin dynamic environment of shale gas source reservoir community".

\section{References}

[1] X.G. Tong. "Origin and distribution of unconventional oil," Acta petrolei Sinica, vol. 33, 2020. (supplement extra edition 1)

[2] C.Y. Liu, F.X. Zhang, F. Gao. "Sedimentary basin reservoir (ore) system," Geology in China, vol. 34, no. 3, 2007.

[3] J.L. Chen, Z.J. Shao, Y. Qin compiling. Energy geology.XuZhou: China University of Mining and Technology Press,2004

[4] Z.F. Jia Zhi-fang. Petroluem geology. Bei Jing: Petroleum Industry Press, 1989

[5] Y.M. Yao, C.Y. Liu, Z.L. Zhao, et al. On evaluation of Jurrasic coal-bearing source rocks and hydrocarbon generation mechanism in Yanqi basin . Acta sedimentologica Sinica, vol. 21, no. 3, pp. 513-521, 2003.

[6] C.B. Che, H.L. Yang, Z.J. Liu, et al. "Exploration and development prospects of oil shale resources in China," China mining magazine, vol. 9, pp. 1-4, 2008.

[7] Y.Song Yan, M.J. Chen, S.F. Cheng et al. Progress in natural gas geological theoryChinese. Petroleum exploration and development 2004(1)

[8] W.Z. Zhao, D.F. He, Y. Song, et al. "China main petroliferous basins onshore basic feature of Petroleum Geology,” Geological Review, vol. 45, no. 3, 1999.

[9] C.N. Zou et al. Unconventional oil and gas geology. Bei Jing:Geology press, 2011

[10] C.L. Liu, C.B. Che , M.Z. Fan, et al. Chinese coalbed methane resource evaluation.China coalbed methane, 2009(3)

[11] H.K. Nie, X. Tang, R.K. Bian Rui-kang. "Shale gas reservoir prediction of favorable areas for ISSN: 0010-8189 
development and controlling factors of shale gas in southern Chinese," Acta petrolei Sinica, vol. 4, pp. 484-491, 2009.

[12] R.S. Chen chief editor.natural gas geology.Wu Han:China university of geosciences press, 1989

[13] C.Y. Zhao, J.Q. Jin. Geology of petroliferous basins. Bei Jing: Petroleum Industry Press, 2011

[14] M.X. Cui. China Energy Development Report in 2007.Bei Jing: The social science literature press, 2007

[15] B.L. Pu, S.J. Bao, Y. Wang Yi et al. "Analysis of reservoir conditions -- to America shale gas basin for example into shale gas," Petroleum Geology and Engineering, vol. 3, pp. 33-35, 2008.

[16] Y. Qin. A review of study on geological coalbed gas Chinese .Geological Journal of China Universities, 2003(3)

[17] Q. Zhao, H.Y. Wang, R.H. Liu et al. "Status of world shale gas development andpresent situation of exploration in China," Natural gas technology, vol. 3, pp. 11-14, 2008.

[18] Chinese Academy of Sciences Energy strategy research group. China's Energy sustainable development Strategy Research Project. Bei Jing: Science Press, 2006

[19] Y.M. Yao, Y.M. Zhang, D.G. Fu, et al. "Relationship between paleotemperature and oil and gas formation in Bohu depression in Yanqi basin," Petroleum exploration and development, vol. 1, pp. 24-27, 2004.

[20] M.C. Li. Petroleum Migration . Bei Jing: Petroleum Industry Press, 2013

[21] J.D. Jia. "Geological features and distribution rule of natural gas reservoirs in Junggar basin," Natural Gas Geoscience, vol. 16, no. 4, pp. 449-455, 2005.

[22] C.Y. Liu, J.F. Zhao, Y.P. Ma, et al. "The formation of present situation and problems of hydrocarbon rich sag characteristics," Earth Science Frontiers, vol. 21, no. 1, 2014. 